\title{
ANALISIS FAKTOR PENENTU PELAKU USAHA MENJUAL MELALUI SITUS JUAL BELI ONLINE BUKALAPAK
}

\author{
Nina Fapari Arif ${ }^{1}$, Asrul Nur ${ }^{2}$ \\ Universitas Fajar Makasar \\ ninafapari@gmail.com
}

\begin{abstract}
The development of the internet continues to increase, with the increasing number of internet users making businessmen easier in selling their products through online, where the businessmen as the of e-commerce businessmen wants an online market place that is easy to use and can be trusted in transacting and selling through online, thus the e-commerce businessmen continues to increase supported by a lot of online trading sites that have already exist in Indonesia. Bukalapak is one of the choices for businessmen to sell and has already had a large number of sellers, that is because of the factors from the characteristics of Bukalapak itself that make the businessmen decide to sell in Bukalapak. This research aims to know the easy factor and trust factor as the determining of businessmen to sell through Bukalapak online sale site. The method used is survey technique with descriptive quantitative approach, where the data obtained from the distribution of online questionnaires by a hundred sellers in Bukalapak as respondents selected. Data analysis use tabulated data presented in the form of percentage graph then it is analyzed descriptively. The result of research show that most of the businessmen selling in Bukalapak agree that the easy factor and trust factor are determining businessmen sell through Bukalapak online sale site.
\end{abstract}

Keywords: The ease of, Confidence, Businessmen, Bukalapak

\begin{abstract}
ABSTRAK
Perkembangan internet terus meningkat, dengan jumlah pengguna internet yang terus meningkat membuat pelaku usaha semakin mudah dalam menjual produknya secara online, dimana pelaku usaha sebagai pelaku $e$ commerce menginginkan online market place yang mudah digunakan dan dapat dipercaya dalam bertransaksi jual beli secara online, dengan demikian pelaku e-commerce semakin bertambah yang didukung dengan banyaknya situs jual beli online yang telah ada di Indonesia. Bukalapak adalah salah satu diantara yang menjadi pilihan para pelaku usaha untuk menjual dan telah memiliki jumlah penjual yang besar, hal tersebut dikarenakan faktor-faktor dari karakteristik bukalapak itu sendiri yang membuat pelaku usaha memutuskan untuk berjualan di Bukalapak. Penelitian ini bertujuan untuk mengetahui faktor kemudahan dan faktor kepercayaan sebagai penentu pelaku usaha menjual melalui situs jual beli online Bukalapak. Metode yang digunakan adalah teknik survey dengan pendekatan kuantitatif deskriptif, dimana data diperoleh dari pembagian kuesioner online kepada seratus penjual di Bukalapak sebagai responden yang terpilih. Analisis data menggunakan tabulasi data yang dipaparkan dalam bentuk grafik persentase kemudian dianalisis secara Deskriptif. Hasil penelitian menunjukkan sebagian besar pelaku usaha yang menjual di Bukalapak menyatakan setuju bahwa faktor kemudahan dan faktor kepercayaan adalah penentu pelaku usaha menjual melalui situs jual beli online Bukalapak.
\end{abstract}

Kata Kunci: Kemudahan, Kepercayaan, Pelaku Usaha, Bukalapak

\section{PENDAHULUAN}

Era yang serba modern ini tidak dapat di pungkiri bahwa batasan geografi bukan lagi suatu persoalan untuk melakukan transaksi jual beli, karena dengan adanya internet pelaku bisnis dan konsumen dapat melakukan transaksi jual beli tanpa harus bertemu secara langsung. Internet telah mengalami perkembangan dan menjadi tempat atau sarana komunikasi dan informasi yang semakin memudahkan manusia dengan adanya internet. Salah satu kemudahan yang terlihat ialah dapat berbelanja kapan pun dan dimana pun saat 
menginginkan suatu produk.Internet tidak hanya sebagai sarana yang memudahkan dalam berbelanja akan tetapi internet juga memudahkan pelaku bisnis dalam memasarkan produknya, kini menjual melalui internet telah menjadi market baru yang potensial. Memasarkan produk untuk pelaku usaha (UKM) tidak lagi membutuhkan biaya yang besar karena dengan adanya internet, produk dapat menjangkau pasar nasional dengan biaya yang terbilang sangat minim.

Jumlah pengguna internet di indonesia berdasarkan hasil survei Asosiasi Penyelenggara Jaringan Internet Indonesia (APJII) mengalami peningkatan sebesar 51,8\% di tahun 2016 dengan jumlah pengguna internet mencapai 132,7 juta pengguna dibandingkan pada tahun 2014 pengguna internet hanya mencapai 88 juta pengguna, jumlah pengguna internet di indonesia telah lebih dari setengah jumlah penduduk indonesia, dimana jumlah penduduknya sebanyak 256,2 juta orang. Gambar dibawah ini menjelaskan pertumbuhan pengguna internet di Indonesia, dimana jumlah pengguna terbesar berada di pulau jawa sebanyak 86,3 juta pengguna di atas Sumatera dan Sulawesi.

Tabel 1.1

Jumlah Pengguna Internet di Indonesia

\begin{tabular}{|l|c|c|}
\hline \multicolumn{1}{|c|}{ Wilayah } & Pengguna & \% \\
\hline Jawa & 86,3 Juta & $65 \%$ \\
\hline Sumatera & 20,7 Juta & $15,5 \%$ \\
\hline Sulawesi & 8,4 Juta & $6,3 \%$ \\
\hline Kalimantan & 7,6 Juta & $5,8 \%$ \\
\hline Bali dan NTB & 6,1 Juta & $4,7 \%$ \\
\hline $\begin{array}{l}\text { Maluku dan } \\
\text { Papua }\end{array}$ & 3,3 Juta & $2,5 \%$ \\
\hline
\end{tabular}

Sumber: Kompas.com, 2016

Berkembangnya pengguna internet memberikan dampak yang besar pada perdagangan online (e-commerce) yang semakin diminati oleh masyarakat dunia terutama Indonesia, dimana Kepala Badan Pusat Statistic (BPS), Suhariyanto mengemukakan sensus 2016 bahwa pengguna e-commerce terus mengalami peningkatan dalam kurung waktu sepuluh tahun terakhir, jumlah e-commerce di Indonesia meningkat sekitar $17 \%$ dengan total jumlah usaha sekitar 26,2 juta usaha e-commerce (Sumber: Liputan6.com). Mengacu pada riset Google yang diungkapkan oleh Wakil Ketua Bidang Penelitian \& Standarisasi Indonesian Ecommerce Association (IDEA), Jonathan Sofian, bahwa pasar e-commerce di Indonesia pada tahun 2013 mencapai Rp. 94,5 triliun. Sedangkan untuk tahun 2016 diperkirakan meningkat 3 kali lipat yang mencapai Rp 295 triliun (sumber: Marketing.com).

Situs jual beli online atau electronic market place adalah suatu bentuk pasar elektronik (virtual market) dimana pembeli dan penjual bertemu dan dihubungkan melalui suatu transaksi elektronik (online) yang dapat diakses secara cepat, aman dan dapat dilakukan dari mana saja dan kapan saja (terbebas dari jam kerja suatu tempat). Electronic market place memiliki keunggulan sebagai tempat berkumpulnya para pelaku usaha menjual barang dagangannya karena mempermudah pencarian pembeli-pembeli baru, penjualan dapat dikembangkan ke segala pelosok dunia, dapat menjadi sarana promosi produk/service 24 jam sehari dan 7 hari seminggu sehingga mengurangi ongkos promosi, mengurangi biaya transaksi dan sales, memperbesar kemungkinan bagi industri kecil untuk ikut serta berkompetisi dalam memasarkan produknya. memungkinkan perusahaan untuk memantau dan menganalisa supply pasar, market demand (permintaan pasar) dan tren pembeli, (Adipranata, 2005).

Pelaku usaha memutuskan membuka online shop di situs jual beli online untuk dapat meningkatkan penjualan, produk dapat dilihat oleh pasar sasaran, sehingga kemungkinan laku terjual lebih besar. Pelaku usaha pun ingin situs jual beli online yang di tempati berjualan mudah digunakan dan dapat dipercaya dalam bertransaksi jual beli online, agar keragu-raguan yang timbul akibat kurangnya kepercayaan pada saat menjual tidak terjadi. 
Oleh karena itu situs jual beli online berlomba-lomba memberikan pelayanan yang baik kepada pelaku e-commerce dalam melakukan transaksi jual beli secara online. Situs jual beli online harus memiliki kelebihan atau pembeda agar pelaku usaha dan konsumen tertarik untuk membeli dan menjual produknya atau setidaknya tertarik untuk berkunjung ke situs jual beli online tersebut.

Tabel 1.2

Online Shop Paling Sering dikunjungi

\begin{tabular}{|c|c|}
\hline ONLINE SHOP & $\%$ \\
\hline 1. LAZADA.CO.ID & 27 \\
\hline 2. TOKOPEDIA.COM & 22 \\
\hline 3. BUKALAPAK.COM & 17 \\
\hline 4. MATAHARIMALL.COM & 8 \\
\hline 5. BLIBLI.COM & 6 \\
\hline 6. TRAVELOKA.COM & 5 \\
\hline 7. ELEVANIA.COM & 4 \\
\hline 8. BHINEKA.COM & 2 \\
\hline 9. Qoo10.CO.ID & 1 \\
\hline 10. TIKET.COM & 1 \\
\hline
\end{tabular}

Sumber : CHIP.CO.ID,2016

Gambar di atas menunjukkan bahwa situs jual beli online yang paling sering di kunjungi oleh netizen (pelaku e-commerce), dimana situs jual beli online Bukalapak.com (17\%) berada di peringkat ketiga di bawah Tokopedia.com (22\%) peringkat ke dua dan Lazada.co.id (27\%) berada di peringkat pertama yang paling sering dikunjungi. Hal ini mencerminkan kehidupan yang serba modern tanpa ada kata batasan dalam hal dunia penjualan yang telah banyak berubah. Pelaku usaha telah beralih dari pemasaran konvensional ke pemasaran online (online marketing) dengan membuka lapak (toko) di situs jual beli online dan salah satu situs jual beli online yang menjadi pilihan ialah Bukalapak yang dikenal penyedia tempat untuk para pelaku usaha (UKM) yang ingin berjualan secara online.

Bukalapak adalah situs jual beli online di Indonesia dengan model bisnis costumer to costumer $(\mathrm{C} 2 \mathrm{C})$ yang bergerak sebagai online market place (tempat pasar online) yang menyediakan tempat berjualan bagi Usaha Kecil Menengah (UKM). Bukalapak menjadi sarana jual beli antara pelaku usaha dan pembeli di mana pun dan kapan pun berkeinginan bertransaksi jual beli secara online dan siapa pun dapat membuka online shop di Bukalapak serta melayani konsumen dari seluruh Indonesia untuk transaksi satuan maupun banyak.

Bukalapak telah dikenal sebagai situs jual beli online yang menargetkan Usaha Kecil Menengah (UKM) Sebagai mitra Bukalapak dengan tujuan Usaha Kecil Menengah (UKM) tidak lagi kesusahan dalam memasarkan produknya berskala nasional. Dalam kurung waktu tujuh tahun, Achmad Zaky, CEO Bukalapak mengungkapkan bahwa jumlah pelaku usaha yang berniaga di Bukalapak pada tahun 2016 sebanyak 1,3 juta pelaku usaha dengan jumlah page view (halaman yang telah dilihat) sekitar 13,4 miliar, sedangkan jumlah transaksi pada tahun 2016 sebesar Rp. 50 miliar untuk transaksi harian (sumber: Seluler.ID).

Pelaku usaha yang semakin besar menggambarkan eksistensinya sebagai situs jual beli online yang besar walau banyaknya pesaing lebih dulu dan bermunculan, akan tetapi Bukalapak tetap menjadi salah satu pilihan untuk berjualan online. Hal tersebut tentunya tidak terjadi begitu saja yang membuat Bukalapak menjadi situs jual beli online dengan jumlah pelaku usaha yang besar, penyebabnya dikarenakan faktor-faktor dari karakteristik Bukalapak itu sendiri sehingga dapat begitu diperhitungkan sebagai salah satu situs jual beli online terkemuka di Indonesia. Faktor-faktor tersebut yang membuat pelaku usaha memutuskan untuk berjualan melalui situs jual beli online di Bukalapak.

\section{TINJAUAN PUSTAKA \\ Pemasaran Online}

Menurut Kotler dan Armstrong (2008), pemasaran online atau online marketing adalah usaha perusahaan untuk memasarkan produk dan pelayanan serta membangun hubungan pelanggan melalui internet. 
Menurut Brenda (2001), mengatakan bahwa E-marketing adalah melakukan bisnis online yang bentuknya paling jelas adalah menjual produk kepada konsumen secara online, sederhananya adalah membuat, mengelola dan meluaskan hubungan komersial secara online. Adapun model bisnis dalam layanan bisnis online (E-marketing) terbagi atas 6 (enam) jenis (Mardiani dan Imanuel, 2013), antara lain:

\section{a) Connectivity, \\ b) Context \\ c) Content \\ d) Communication \\ e) Community \\ f) Commerce}

Dari pernyataan diatas dapat disimpulkan online marketing sesuai dengan pernyataan dari pengamat $e$-business Rudianto Prabowo, melihat perusahaan yang melakukan online marketing ada dua perspektif, yaitu:

1. Perusahaan brick and click Artinya perusahaan yang melakukan transaksi di dua channel (offline dan online)

2. Perusahaan pure play Artinya perusahaan yang benar-benar melakukan transaksi hanya di dunia maya. Diluar itu adalah perusahaan brick and mortar, yaitu perusahaan pada umumnya hanya ada di dunia nyata.

\section{E-Commerce}

Menurut Rahmati dalam Irmawati (2011), E-commerce singkatan dari Electronic Commerce yang artinya sistem pemasaran secara atau dengan media elektronik. $E$ Commerce ini mencakup distribusi, penjualan, pembelian, marketing dan service dari sebuah produk yang dilakukan dalam sebuah system elektronika seperti Internet atau bentuk jaringan komputer yang lain.

E-commerce adalah penyebaran, pembelian, penjualan, pemasaran barang dan jasa melalui sistem elektronik seperti internet atau televisi, www, atau jaringan komputer lainnya. E-commerce dapat melibatkan transfer dana elektronik, pertukaran data elektronik, jaringan komputer lainnya. Ecommerce dapat melibatkan transfer dana elektronik, pertukaran data elektronik sistem inventori otomatis, dan sistem pengumpulan data otomatis. Sehingga dapat dikatakan bahwa e-commerce merupakan suatu pemasaran barang atau jasa melalui sistem informasi yang memanfaatkan teknologi informasi.

E-commerce dilakukan di internet yang salah satu satu caranya melalui website (Situs Web) merupakan kumpulan dari halamanhalaman web yang berhubungan dengan filefile lain yang terkait. Dalam sebuah website terdapat suatu halaman yang dikenal dengan sebutan home page. Home page adalah sebuah halaman yang pertama kali dilihat ketika seseorang mengunjungi website. Dari home page, pengunjung dapat mengklik hyperlink untuk pindah ke halaman lain yang terdapat dalam website tersebut (Andrian \& Hendriyanto, 2014).

\section{Pengelolaan Ecommerce}

Penggolongan e-commerce pada umumnya dilakukan berdasarkan sifat transaksinya. Menurut (Laudon and Laudon 2007), penggolongan e-commerce dibedakan sebagai berikut:

1. Business to Consumer (B2C),

2. Business to Business (B2B).

3. Consumer to Consumer $(\mathrm{C} 2 \mathrm{C})$.

4. Peer-to-peer $(P 2 P)$.

5. Mobile Commerce (M-Commerce)

E-commerce yang dimaksud dalam penelitian ini termasuk ke dalam golongan Business to Business (B2B), yang meliputi transaksi jual, beli, dan pemasaran kepada pembeli dengan menggunakan media internet melalui penyedia tempat (situs) jual beli online Bukalapak (www.bukalapk.com). Dalam proses transaksi e-commerce, baik itu $\mathrm{B} 2 \mathrm{~B}$ maupun $\mathrm{C} 2 \mathrm{C}$, situs jual beli online Bukalapak bekerja sama dengan jasa perbankan sebagai institusi yang menangani transfer pembayaran transaksi.

Metode Pembayaran di E-Commerce 
Adapun metode pembayaran $E$ commerce yang biasa digunakan dalam transaksi menggunakan e-commerce yaitu:

1. Online Processing Credit Cart

2. Money Transfer

3. Cash on Delivery

\section{Kemudahan}

Menurut Davis (1989) mendefinisikan kemudahan digunakan (ease of use) sebagai suatu tingkatan dimana seseorang percaya bahwa suatu teknologi dapat dengan mudah digunakan. Situs harus dirancang dengan baik sehingga konsumen dapat cepat mendapatkan informasi produk yang diinginkan. Beberapa temuan empiris menunjukkan bahwa kemudahan akses situs belanja ritel online mampu meningkatkan kepuasan pelanggan,

Adapun beberapa indikator kemudahan penggunaan teknologi informasi (Davis, 1989):

1. Teknologi informasi (TI) sangat mudah dipelajari.

2. TI mengerjakan dengan mudah apa yang diinginkan oleh Pengguna.

3. Keterampilan pengguna akan bertambah dengan menggunakan TI.

4. TI sangat mudah untuk dioperasikan.

Selain itu, kemudahan digunakan juga merupakan faktor utama yang berpengaruh terhadap penggunaan online shopping. Kemudahan akan mengurangi usaha (baik waktu dan tenaga) seseorang di dalam mempelajari sistem online. Jika dikaitkan dengan sistem berbelanja online, kemudahan dapat diindikasikan bahwa pembeli yang memiliki pengetahuan tentang online shopping tidak mengalami kesulitan ketika berbelanja online dibandingkan pembeli yang tidak memiliki pengetahuan tersebut. Pembeli online percaya bahwa web siteonline shopping yang lebih fleksibel, mudah dipahami dan mudah pengoperasiannya sebagai karakteristik kemudahan.

\section{Kepercayaan}

Kepercayaan (Trust) merupakan keyakinan satu pihak mengenai maksud dan perilaku pihak yang lainnya. Dengan demikian kepercayaan konsumen didefinisikan sebagai harapan konsumen bahwa penyedia jasa dapat dipercaya atau diandalkan dalam memenuhi janjinya. menyebut kepercayaan sebagai kredibilitas, dalam penelitiannya mengartikan kredibilitas sebagai sejauh mana pembeli percaya bahwa pemasok memiliki keahlian untuk melakukan aktivitas secara efektif dan andal. Kepercayaan berhubungan dengan niat perusahaan untuk mengandalkan mitra pertukaran mereka. Kepercayaan sebagai sebuah kebajikan, karena didasarkan pada sejauh mana perusahaan percaya bahwa mitranya memiliki niat dan motif-motif yang menguntungkan (Siagian \& Cahyono, 2014).

(Siagian \& Cahyono, 2014) Online trust dibentuk oleh tiga elemen penting yaitu integrity, ability, dan benevolence. Dalam konteks online, integrity merupakan kepercayaan konsumen bahwa sebuah institusi atau sumber informasi online akan mampu menyampaikan informasi secara jujur dan dapat terpercaya. Ability merupakan kepercayaan konsumen bahwa sebuah institusi atau sumber informasi online memiliki kemampuan dan kompetensi untuk menyediakan informasi yang dapat diandalkan tentang produk. Benevolence merupakan kepercayaan konsumen bahwa sebuah institusi atau sumber informasi online mempertimbangkan kepentingan konsumen dan kemaslahatan orang banyak dalam menjalankan aktivitas penyampaian informasi online tersebut.

Kepercayaan (trust) menjadi katalisator bagi transaksi penjual dan pembeli yang membuat konsumen memiliki harapan besar untuk puas terhadap hubungan tukar-menukar tersebut (Featherman \& Pavlou, 2003). Kepercayaan (trust) terhadap electronic vendor menentukan putusan konsumen untuk melakukan hubungan penyedia bisnis $e$ commerce (Friedman, 2003).

Saat konsumen membeli produk-produk dalam kehidupan sehari-hari, merek (brand) dan citra (image) merupakan hal-hal yang sangat mempengaruhi perilaku pembelian konsumen. Jika suatu perusahaan bukanlah 
perusahaan yang memiliki merek ternama, dan konsumen-konsumen perusahaan tersebut dapat berpindah layanan bagaimana perusahaan tersebut memelihara hubungan dengan para konsumen yang bersangkutan. Inilah yang dinamakan sebagai membangun loyalitas (kesetiaan) konsumen. pada umumnya, loyalitas para konsumen muncul dari interaksi yang terus-menerus secara intensif dengan perusahaan tersebut. Sepanjang perusahaan dapat menyediakan informasi yang bermanfaat dan bernilai kepada konsumen, mereka pasti akan menganggap perusahaan sebagai rekanan (partner) yang dapat dipercaya.

(Gefen \& Straub, 2004) memperoleh bukti empiris bahwa structural assurance berpengaruh terhadap timbulnya trust terhadap sistem e-commerce. Structural assurance mengacu pada penilaian adanya mekanisme keamanan jaringan sistem electronic commerce yang memadai. Keyakinan terhadap struktur muncul karena pengguna yakin bahwa teknologi sistem e-commerce memberikan perlindungan sehingga konsumen yakin bahwa transaksi melalui internet dapat berjalan aman.

\section{METODOLOGI PENELTIAN}

\section{Rancangan Penelitian}

Penelitian ini menggunakan pendekatan deskriptif kuantitatif dengan teknik survey, yaitu dengan mengumpulkan data melalui kuesioner online, mengenai faktor-faktor penentu pelaku usaha menjual melalui situs jual beli online Bukalapak, dimana faktor kemudahan dan kepercayaan sebagai fokus penelitian yang menjadi tolak ukur penentu pelaku usaha menjual melalui situs jual beli online Bukalapak. maksud dari penelitian ini untuk mengetahui faktor kemudahan dan kepercayaan sebagai penentu pelaku usaha di situs Bukalapak.

penelitian deskriptif kuantitatif ini bertujuan untuk menjelaskan suatu situasi yang hendak diteliti dengan dukungan angkaangka serta temuan-temuan melalui kuesioner dan observasi yang dideskripsikan secara tertulis mengenai faktor kemudahan dan kepercayaan yang menjadi penentu pelaku usaha menjual melalui situs jual beli online Bukalapak.

\section{Tempat dan waktu Penelitian}

Lokasi penelitian ini adalah di situs jual beli online Bukalapak (online market place), artinya lokasi penelitian dilakukan di dalam dunia maya (internet) yang akan dipusatkan pada beberapa pelaku usaha yang terpilih dari seluruh pelaku usaha yang berjualan melalui situs jual beli online Bukalapak yang dianggap dapat memenuhi informasi yang dibutuhkan. Sedangkan waktu penelitian 20 Mei s.d. tanggal 05 Juli 2017.

\section{Populasi dan Sampel}

Pada penelitian ini, penulis menjadikan seluruh pelaku usaha (pelapak) yang berjualan melalui situs jual beli online Bukalapak sebagai populasi dengan total populasi sebanyak 1.300 .000 pelaku usaha.

Adapun Jumlah sampel yang diperoleh dengan menggunakan rumus Slovin Dengan demikian, perolehan jumlah sampel yang digunakan sebagai responden dalam penelitian ini sebanyak 100 (seratus) orang pelaku usaha.

\section{Teknik Pengumpulan Data}

Dalam memperoleh data yang dibutuhkan sebagai bahan pembuatan hasil penelitian, ada beberapa teknik, cara atau metode yang dilakukan oleh peneliti dan disesuaikan dengan situasi dan kondisi yang diteliti, yaitu:

1. Kuesioner online

2. Observasi

3. Studi Literatur

\section{HASIL DAN PEMBAHASAN}

Data penelitian yang telah diolah kemudian dihasilkan nilai rata-ratanya yang dianalisis untuk mendapatkan gambaran deskriptif mengenai variabel-variabel penelitian yang diukur kebenarannya, sehingga setiap item pertanyaan dapat diketahui tingkat penentu yang membuat para pelaku usaha menjual di situs jual beli online Bukalapak. Dalam penelitian ini digunakan alat ukur skala Guttman yang disebar melalui kuesioner online. 


\section{Hasil Rata-Rata Faktor Kemudahan}

Kemudahaan penggunan yang dimakud adalah kemampuan pelaku usaha dalam menggunakan situs jual beli online Bukalapak dalam menjual, dimana penelitian ini menggunakan sembilan item pertanyaan yang dikembangkan dari empat indikator kemudahan yang digunakan untuk mengukur seberapa besar tingkat faktor kemudahan sebagai penentu pelaku usaha menjual melalui situs jual beli online Bukalapak. Hasil yang diperoleh dari 100 responden diukur menggunakan teknik tabulasi data (distribusi frekuensi) yang disajikan dalam bentuk grafik persentase. Berikut pemaparan rata-rata setiap item pertanyaan dan rata-rata variabel kemudahan untuk mengetahui tingkat kategori persentase terbesar, yaitu, tidak ada (0\%-1\%), sebagian kecil (2\%-25\%), kurang dari setengah (26\%-49\%), setengah (50\%), lebih dari setengah (51\%-75\%), sebagian besar (76\%-99\%) atau seluruh (100\%) setuju atau tidak setuju sebagai penentu pelaku usaha menjual di situs jual beli online Bukalapak, adalah:

Tabel 4.1

Persentase Jawaban Responden Item Kemudahan

\begin{tabular}{|c|c|c|c|}
\hline \multirow[t]{2}{*}{ NO } & \multirow{2}{*}{$\begin{array}{c}\text { BUTIR } \\
\text { PERTANYAAN }\end{array}$} & \multicolumn{2}{|c|}{$\begin{array}{c}\text { PERSENTASE } \\
(\%)\end{array}$} \\
\hline & & YA & TIDAK \\
\hline \multicolumn{4}{|c|}{ KEMUDAHAN } \\
\hline 1 & $\begin{array}{lr}\text { Tampilan } & \text { (fitur- } \\
\text { fitur) yang terdapat } \\
\text { di situs Bukalapak } \\
\text { mudah } & \text { untuk } \\
\text { dipahami } & \text { dalam } \\
\text { menjual. } & \end{array}$ & 92 & 8 \\
\hline 2 & $\begin{array}{l}\text { Pelaku usaha } \\
\text { dipermudah } \\
\text { menjual dengan } \\
\text { adanya panduan } \\
\text { berjualan di situs } \\
\text { Bukalapak }\end{array}$ & 93 & 7 \\
\hline 3 & $\begin{array}{l}\text { Apa yang diakses } \\
\text { atau melakukan } \\
\text { perbaharuan lapak } \\
\text { direspon dengan } \\
\text { cepat oleh situs } \\
\text { Bukalapak. }\end{array}$ & 92 & 8 \\
\hline
\end{tabular}

\begin{tabular}{|c|c|c|c|}
\hline 4 & $\begin{array}{l}\text { Customer Servis } \\
\text { (CS) Bukalapak } \\
\text { cepat menanggapi } \\
\text { komplain. }\end{array}$ & 79 & 21 \\
\hline 5 & $\begin{array}{l}\text { Telah merasa } \\
\text { leluasa } \\
\text { menggunakan situs } \\
\text { web/apk } \\
\text { Bukalapak dalam } \\
\text { berjualan. }\end{array}$ & 91 & 9 \\
\hline 6 & $\begin{array}{l}\text { Komunitas } \\
\text { Bukalapak } \\
\text { membantu dalam } \\
\text { menjual di situs } \\
\text { Bukalapak }\end{array}$ & 83 & 17 \\
\hline 7 & $\begin{array}{l}\text { Situs Bukalapak } \\
\text { mudah dalam hal } \\
\text { proses penerimaan } \\
\text { pesanan } \\
\text { (pengurusan } \\
\text { registrasi). }\end{array}$ & 93 & 7 \\
\hline 8 & $\begin{array}{l}\text { Fitur chat } \\
\text { membantu } \\
\text { berkomunikasi } \\
\text { dengan pembeli }\end{array}$ & 95 & 5 \\
\hline 9 & $\begin{array}{lr}\text { Terbantu dalam } \\
\text { menjual dengan } \\
\text { menggunakan fitur } \\
\text { paket } \\
\text { Push/Promod Push } \\
\text { atau Premium } \\
\text { Account rang } \\
\text { disediakan } & \text { situs } \\
\text { Bukalapak } & \\
\end{array}$ & 78 & 22 \\
\hline & Rata-Rata & 88,4 & 11,6 \\
\hline
\end{tabular}

nilai rata-rata variabel kemudahan yang dipersentasekan dari pendapat 100 responden untuk sembilan item pertanyaan variabel kemudahan, sehingga diperoleh nilai persentase YA (setuju) sebesar $88 \%$ $(88,444444444 \%)$ dan nilai persentase TIDAK (tidak setuju) sebesar 12\% (11,55555556\%). Hasil tersebut menandakan kategori persentase terbesar variabel kemudahan adalah sebagian besar (88\%) pelaku usaha yang menjual di situs Bukalapak setuju mengenai faktor kemudahan sebagai penentu pelaku usaha menjual melalui situs jual beli online Bukalapak.

Adapun pertanyaan yang meminta pendapat terkait kemudahan yang dipaparkan oleh para pelaku usaha yang terpilih sebagai 
responden yaitu mengenai kemudahan yang dirasakan selama menjual di situs jual beli online Bukalapak sebaagi online market place yang menyediakan tempat bagi para pelaku usaha dalam menjual secara online, ditanyakan secara terbuka atau pendapat langsung responden dalam kuesioner online yang disebar.

Para pelaku usaha berpendapat bahwa Bukalapak adalah market place yang mudah di gunakan atau user frendly karena simpel atau tidak ribet, mudah dalam pembuatan akun seller, mudah dalam upload barang jualan, mudah di temukan di searc engine, dipermudah dengan adanya fitur promosi baik itu Paket Push/Promote Push ataupun Premium Accuont, walau harganya yang mahal, serta dimudahkan dalam menjual dengan bantuan CS (custumer service) yang cepat menanggapi komplain para pelaku usaha dan bantuan komunitas di kota masing-masing pelaku usaha sangat membantu dalam menjual di situs jual beli online Bukalapak. walau demikian adapun pelaku usaha yang berpendapat bahwa Bukalapak memiliki interface yang biasa dari market place lainnya, postingan barang jualan yang sering hilang dalam lapak, serta fitur chat yang sering eror dalam berkomunikasi dengan calon pembeli, cek ongkos kirim yang tidak akurat.

Kemudahan merupakan aspek pertama yang diukur dalam penelitian ini untuk mengetahui seberapa besar kemudahan yang dirasakan oleh pelaku usaha dalam menjual yang sebagai penentu menjual melalui situs jual beli online Bukalapak. Dari hasil perhitungan tabulasi data (distribusi frekuensi), dihasilkan pendapat dari 100 responden bahwa kategori persentase terbesar ialah sebagian besar (88\%) responden menyatakan setuju mengenai variabel kemudahan atau faktor kemudahan penentu pelaku usaha menjual melalui situs jual beli online Bukalapak. Hal ini diperkuat dengan adanya hasil perhitungan sembilan pertanyaan dalam variabel kemudahan yang menyatakan Ya (setuju).
Pertanyaan ini meliputi teknologi informasi (TI) sangat mudah dipelajari (dua pertanyaan), TI mengerjakan dengan mudah apa yang diinginkan oleh pengguna (dua pertanyaan), Keterampilan pengguna akan bertambah dengan menggunakan TI (dua pertanyaan), dan TI sangat mudah untuk dioperasikan (tiga pertanyaan) yang rata-rata kategori persentasenya sebagian besar pelaku usaha yang menjual di Bukalapak setuju sebagai jawaban tertinggi. Dimana bukalapak sangat mudah dipelajari karena memiliki fiturfitur yang mudah di pahami dan memiliki panduan dalam berjualan. Bukalapak memproses permintaan dengan mudah baik mengakses atau melakukan perbaharuan lapak direspon dengan cepat (tidak looding) dalam waktu yang lama walau konektivitas jaringan bagus serta CS (customer servis) Bukalapak cepat merespon tanggapan penjual bila ada komplain yang diajukan.

Bukalapak juga meningkatkan keterampilan pelaku usaha dalam menjual di situs Bukalapak karena pelaku usaha telah merasa leluasa menggunakan situs web/apk Bukalapak dalam berjualan serta terbantu dengan adanya komunitas yang mempertemukan atara penjual dengan tujuan saling berbagi ilmu dan membantu dalam menjual. Bukalapak adalah situs yang sangat mudah di operasikan dalam menjual dengan menggunakan fitur Paket Push/Promod Push atau Premium Account yang disediakan situs Bukalapak dapat meningkatkan penjualan, dibantu dengan fitur chat berkomunikasi dengan calon pembeli dalam proses transaksi, serta proses penerimaan pesanan yang mudah. Sehingga variabel kemudahan terbukti sebagai penentu pelaku usaha menjual melalui situs jual beli online bukalapak. Hasil ini senada dengan teori yang dikemukakan oleh Davis (1989) tentang kemudahan digunakan (ease of use) sebagai suatu tingkatan dimana seseorang percaya bahwa suatu teknologi dapat dengan mudah digunakan. Kemudahan digunakan juga merupakan faktor utama yang berpengaruh terhadap penggunaan online shopping. Kemudahan akan mengurangi usaha (baik 
waktu dan tenaga) seseorang di dalam mempelajari sistem online.

Sedangkan untuk tingkat kategori persentase terkecil atau tidak setuju faktor kemudahan penentu pelaku usaha menjual melalui situs jual beli online Bukalapak dengan presentase sebesar 12\%, dimana pelaku usaha berpendapat bahwa Bukalapak memiliki interface yang biasa dari market place lainnya, postingan barang jualan yang sering hilang dalam lapak, serta fitur chat yang sering eror dalam berkomunikasi dengan calon pembeli, cek ongkos kirim yang tidak akurat atau tidak update yang membuat pelaku usaha sering kesusahan menghubungi pihak Bukalapak atau pembeli bahwa pembayaran ongkos kirim tidak sesuai.

\section{Hasil Rata-Rata Faktor Kepercayaan}

Kepercayan yang dimaksud adalah rasa percaya yang diberikan para pelaku usaha (pelaku usaha) kepada situs jual beli online Bukalapak dalam menjual. dimana untuk mengetahui seberapa besar tingkat rata-rata faktor kepercayaan sebagai penentu pelaku usaha menjual melalui situs jual beli online Bukalapak menggunakan tujuh item pertanyaan yang dikembangkan dari tiga indikator kepercayaan. Hasil yang diperoleh dari 100 responden diukur menggunakan teknik tabulasi data (distribusi frekuensi) yang disajikan dalam bentuk grafik persentase. Berikut pemaparan rata-rata setiap item pertanyaan dan rata-rata variabel kepercayaan untuk mengetahui tingkat kategori persentase terbesar. yaitu, tidak ada $(0 \%-1 \%)$, sebagian kecil (2\%-25\%), kurang dari setengah (26\%$49 \%)$, setengah $(50 \%)$, lebih dari setengah (51\%-75\%), sebagian besar (76\%-99\%) atau seluruh $(100 \%)$ setuju atau tidak setuju sebagai penentu pelaku usaha menjual di situs jual beli online Bukalapak:

\section{Tabel 4.2}

Persentase Jawaban Responden Item Keepercayaan

\begin{tabular}{|c|l|c|c|}
\hline \multirow{2}{*}{ NO } & \multirow{2}{*}{$\begin{array}{c}\text { BUTIR } \\
\text { PERTANYAAN }\end{array}$} & \multicolumn{2}{|c|}{$\begin{array}{c}\text { PERSENTASE } \\
(\boldsymbol{\%})\end{array}$} \\
\cline { 3 - 4 } 1 & YA & TIDAK \\
\hline \multirow{4}{|c|}{ KEPERCAYAAN } \\
\hline \multirow{2}{*}{$\begin{array}{l}\text { Pelaku usaha } \\
\text { percaya dengan } \\
\text { Rekening Bersaman } \\
\text { (BL Payment }\end{array}$} & 100 & 0 \\
\hline
\end{tabular}

\begin{tabular}{|c|c|c|c|}
\hline & $\begin{array}{l}\text { System) yang } \\
\text { berlaku di situs } \\
\text { Bukalapak. }\end{array}$ & & \\
\hline 2 & $\begin{array}{lr}\text { Pelaku } & \text { usaha } \\
\text { percaya } & \text { situs } \\
\text { Bukalapak akan } \\
\text { mengelolah uang } \\
\text { dengan baik di } \\
\text { Bukadopet. }\end{array}$ & 91 & 9 \\
\hline 3 & $\begin{array}{lr}\text { Pelaku } & \text { usaha } \\
\text { percaya } & \text { situs } \\
\text { Bukalapak } & \\
\text { menyediakan } & \\
\text { berbagai } & \text { fitur } \\
\text { promosi } & \text { (paket } \\
\text { Push/Promod } & \text { push } \\
\text { dan } & \text { Premium } \\
\text { Account) } & \text { untuk } \\
\text { berjualan } & \text { akan } \\
\text { menguntungkan. }\end{array}$ & 78 & 22 \\
\hline 4 & $\begin{array}{lr}\text { Pelaku } & \text { usaha } \\
\text { percaya bahwa } \\
\text { Bukalapak akan } \\
\text { mengirimkan } \\
\text { pembayaran barang } \\
\text { setelah sampai ke } \\
\text { konsumen. }\end{array}$ & 96 & 4 \\
\hline 5 & $\begin{array}{ll}\text { Pelaku usaha yang } \\
\text { ingin pinjam uang } \\
\text { atau } & \text { telah } \\
\text { meminjam } & \text { uang } \\
\text { melalui Bukamodal } \\
\text { percaya akan di } \\
\text { untungkan. }\end{array}$ & 63 & 37 \\
\hline 6 & $\begin{array}{l}\text { Percaya semua fitur } \\
\text { yang tersedia di } \\
\text { situs Bukalapak } \\
\text { untuk kepentingan } \\
\text { pelaku usaha dalam } \\
\text { menjual }\end{array}$ & 72 & 28 \\
\hline 7 & $\begin{array}{lr}\text { Selama } & \text { menjual } \\
\text { selalu } & \text { diuntungkan } \\
\text { dalam } & \text { setiap } \\
\text { transaksi } & \text { yang } \\
\text { terjadi } & \text { di } \\
\text { Bukalapak. } & \end{array}$ & 70 & 30 \\
\hline & Rata-Rata & 81,4 & 18,6 \\
\hline
\end{tabular}

nilai rata-rata variabel kemudahan yang dipersentasekan dari pendapat 100 responden 
untuk tujuh item pertanyaan variabel kemudahan, sehingga diperoleh nilai persentase YA (setuju) sebesar $81 \%$ $(81,42857143 \%)$ dan nilai persentase TIDAK (tidak setuju) sebesar 19\% (18,57142857\%). Hasil tersebut menandakan kategori persentase terbesar variabel kepercayaan ialah sebagian besar $(81 \%)$ pelaku usaha yang menjual di situs Bukalapak setuju mengenai faktor kepercayaan sebagai penentu pelaku usaha menjual melalui situs jual beli online Bukalapak,

Adapun pertanyaan yang meminta pendapat dari responden terkait kepercayaan yang dirasakan salama menjual Bukalapak, ditanyakan secara terbuka atau pendapat langsung dari pelaku usaha yang terpilih sebagai responden mengenai kepercayaan yang dimilikinya terhadap Bukalapak sebaagi online market place yang menyediakan tempat bagi para pelaku usaha dalam menjual secara online.

Para pelaku usaha berpendapat bahwa situs jual beli online Bukalapak adalah market place terpercaya dengan sistem yang aman dengan prosedur atau aturan yang jelas antara penjual dan pembeli, Bukalapak dengan sistem rekening bersama (BL Payment System) membuat para calon buyer (pembeli) tidak takut uang tidak kembali apabila barang tidak dikirim yang membuat para seller percaya bahwa Bukalapak akan mengirimkan uang pembelian barang setelah barang sampai kepada pembeli, walau terkadang pencairan dana terlambat dari rekening bersama di transfer ke bukadompet milik penjual. Bukalapak juga dipercaya karena dengan adanya komunitas Bukalapak orang dalam (pegawai Bukalapak) ikut bergabung dalam komunitas yang menghubungkan antara seller dan pihak Bukalapak langsung. Adapun pelaku usaha yang berpendapat bahwa Bukalapak lebih mengutamakan atau berpihak kepada pembeli daripada pelaku usaha (seller), Bukalapak money oriented karena fitur prabayar yang mahal dan fitur Bukamodal masih bersistem bunga padahal yang diharapkan bagi hasil.
Kepercayaan merupakan aspek kedua yang diukur dalam penelitian ini untuk mengetahui seberapa besar variabel kepercayaan yang dirasakan oleh pelaku usaha kepada Bukalapak dalam menjual sebagai penentu pelaku usaha menjual melalui situs jual beli online Bukalapak. Dari hasil perhitungan tabulasi data (distribusi frekuensi), dihasilkan pendapat dari 100 responden bahwa kategori persentase terbesar ialah sebagian besar (81\%) responden menyatakan setuju mengenai variabel kepercayaan atau faktor kepercayaan penentu pelaku usaha menjual melalui situs jual beli online Bukalapak. Hal ini diperkuat dengan adanya hasil perhitungan tujuh pertanyaan dalam variabel kepercayaan yang menyatakan Ya (setuju).

Pertanyaan tersebut meliputi integrity (dua pertanyaan), ability (dua pertanyaan), dan benevolence (tiga pertanyaan) yang rata-rata kategori persentasenya sebagian besar kecuali untuk indikator benevolence yang ketiga pertanyaan kategori persentasenya lebih dari setengah pelaku usaha yang menjual di Bukalapak setuju sebagai jawaban tertinggi. Dimana Bukalapak menyampaikan informasi secara jujur dan dapat terpercaya dengan kepercayaan pelaku usaha terhadap Rekening Bersaman (BL Payment System) yang berlaku di situs Bukalapak dan pelaku usaha percaya kepada situs Bukalapak akan mengelolah uang mereka dengan baik di Bukadopet. Bukalapak dipercaya memiliki kemampuan dan kompetensi untuk menyediakan informasi yang dapat diandalkan tentang produk seperti menyediakan berbagai fitur promosi (paket Push/Promod push dan Premium Account) untuk berjualan dan pelaku usaha percaya Bukalapak akan mengirimkan pembayaran barang setelah sampai ke konsumen.

Bukalapak juga dipercaya sebagai online market place yang mengutamakan kepentingan bersama yang tidak lain ialah seller atau pelaku usaha yang disediakan peminjaman uang dengan fitur Bukamodal, pelaku usaha percaya Bukalapak menyediakan semua fitur di situs Bukalapak untuk 
kepentingan para pelaku usaha serta pelaku usaha yang menjual di Bukalapak selalu diuntungkan dalam setiap transaksi yang terjadi. Sehingga variabel kepercayaan terbukti penentu pelaku usaha menjual melalui situs jual beli online Bukalapak. Hasil ini senada dengan teori yang dikemukakan oleh Menurut (Gefen \& Straub, 2003) mengenai kepercayaan dibentuk oleh tiga elemen penting yaitu integrity, ability dan benevolence dalam konteks online.

\section{KESIMPULAN}

Secara umum hasil penelitian yang diperoleh memuaskan dimana kedua faktor yang teliti yaitu faktor kemudahan dan faktor kepercayaan penentu pelaku usaha menjual di situs jual beli online Bukalapak dengan tingkat kategori persentase terbesar, dimana yang berpendapat YA (setuju) sebagian besar, dengan kata lain faktor kemudahan dan faktor kepercayaaan sebagai salah dua tolak ukur yang di jadikan penentu oleh pelaku usaha untuk berjualan melalui situs juala beli online Bukalapak.

Sedangkan sebagaian kecil pelaku usaha berpendapat dari segi kemudahan bahwa situs jual beli online Bukalapak memiliki interface yang biasa dari market place lainnya, postingan barang jualan yang sering hilang dalam lapak, dan fitur chat yang sering eror dalam berkomunikasi dengan calon pembeli serta cek ongkos kirim yang tidak update atau diperbaharui. Dari segi kepercayaan sebagian kecil pelaku usaha berpendapat bahwa situs jual beli online Bukalapak lebih mengutamakan atau berpihak kepada pembeli daripada pelaku usaha (seller) karena uang pembeli tetap dikembalikan walau barang telah dikirim yang diakibatkan nomor resi pengiriman yang belum di imput sedangkan masa waktu pengiriman telah habis, Bukalapak telah identik dengan uang karena fitur prabayar yang mahal, dan mengahrapkan Bukamodal memiliki sistem bagi hasil agar pelaku usaha lebih percaya akan diuntungkan dalam menggunakan fitur tersebut.

\section{DAFTAR PUSTAKA}

Andrian, H. R., \& Hendriyanto, R. (2014). Usulan Pembangunan Model Prototype Layanan Cloud Computing - Saas Portal Konten Untuk Membangun Konten Pedesaan. Seminar Nasional Teknologi Informasi Dan Multimedia 2014. https://doi.org/10.1039/C7DT00319F Adipranata, Rudy (2005). Perancangan dan Pembuatan Aplikasi Segmentasi Fambar dengan Menggunakan Metode Morphological Watershed. Surabaya : Universitas Kristen Petra

Anderson, E. and Weitz (B) 1989,

Determinants of continuity in conventional industrial dyads , marketing science, vol.8 , pp 310-23

Brenda Kienan (2001), Small Business

Solutions E-Commerce Alex Media

Kompulindo, Jakarta

Bungin, Burhan (2001) Metodologi Penelitian Kualitatif Dan Kuantitatif. Yogyakarta:Gajah Mada Press.

Davis, F. D. (1989). Davis 1989.pdf.

Information Technology. https://doi.org/10.2307/249008

Doney, P.M., and Cannon, J.P., 1997, “An Examination of The Nature of Trust in Buyer - Seller Relationship, "Journal of Marketing”April, pp. 35-51

Faisal, Sanapiah. 1990, Penelitian Kualitatif: Dasar-dasar dan Aplikasi, Yayasan Asih Asah Asuh Malang (YA3 Malang), Edisi 1, Cet 1

Featherman, M. S., \& Pavlou, P. A. (2003). Predicting e-services adoption: A perceived risk facets perspective. International Journal of Human Computer Studies. https://doi.org/10.1016/S10715819(03)00111-3

Friedman, K. (2003). Theory construction in design research Criteria: Approaches, and methods. In Design Studies. https://doi.org/10.1016/S0142694X(03)00039-5 
Friedman, E.A. 2003. Coping With The Coming Pandemic Of Renal Failure Due To Diabetes Mellitus.FactaUniversitatis Series : Medicine and Biology. 10: 1-15

Ganesan, S. 1994. Determinants of long-term orientation in buyer-seller relationship. Journal of Marketing. 58: 1-19.

Gefen, D., \& Straub, D. (2003). Managing User Trust in $\mathrm{B} 2 \mathrm{C}$ e-Services. E-Service Journal. https://doi.org/10.2979/ESJ.2003.2.2.7

Gefen, D., \& Straub, D. W. (2004). Consumer trust in $\mathrm{B} 2 \mathrm{C}$ e-Commerce and the importance of social presence: Experiments in e-Products and eServices. Omega. https://doi.org/10.1016/j.omega.2004.01. 006

Gefen, D and Straubb, D.W (2004). Consumer Trust in B2C e-Commerce and The Importance of Social Presence: Experiments in e-Products and eServices . Omega 32, $407-424$.

hattacharjee G, Chaudari PS. 2002. Cocoon production morphology hatching pattern and fecundity in seven tropical earthworm species a laboratory based investigation. J. Biosci. 27(3): 283-294.

Irmawati, Dewi 2011. "Pemanfaatan ecommerce dalam Dunia Bisnis", Jurnal Ilmiah Orasi Bisnis , Edisi ke-VI

Juanita, H.A.,\& Lestari, U.P.2015. Tingkat Kepercayaan Konsumen dan Pemanfaatan E-Marketing terhadap Keputusan Pembelian Konsumen Produk E-Ticket Pesawat di Octopus Travel Surabaya. Ebis. Vol. 7. No 1(5574)

Jarvenpaa, S.L., Tractinsky, N., and Vitale, (2000), M. Consumer trust in an Internet store. Information Technology and Management, 1, 1-2 .45-71

Kotler, Philip dan Gaey AMstrong , 2008. Prinsip-Prinsip Pemasaran, Edisi 12 , Erlangga Jakarta.
Kountur, R. 2004. Metode Penelitian Untuk Penulisan Skripsi dan Tesis, Jakarta: PPM

Kusumasodjaja, Sony 2014 , "E-bisnis dan Ecommerce"Yogyakarta

Laudon, Kenneth C., dan Laudon . Jane P., “ Management Information System", $10^{\text {th }}$ Ed, Jakarta : Salemba Empat, 2007.

Lohse, Gerald, and Spiller. 1998. "Electronic Shopping Association for Computing Machinery", Communications of The ACM, ABI/Inform Research, Pge 81.

Mardiani, I.E., dan Imanuel, O.J.,(2013),'Analisis Keputusan Pembelian Konsumen melalui Media Online (E-Marketing)', Jurnal Ekonomi, Vol.4, No.2, pp.153-154

McKnight, D. H Choudhury, and Kacmar, C. (2002).Special Issue on Measuring eCommerce in Net-Enabled Organizations, Part 2 of 2: Developing and Validating Trust Measures for e Commerce: An Integrative Typology Information Systems Research 13:334359

Pavlou, P. A. (2003). Consumer Acceptance of Electronic Commerce: Integrating Trust and Risk with the Technology Acceptance Model. International Journal of Electronic Commerce, 7 (3), $69-103$.

Siagian, H., \& Cahyono, E. (2014).

ANALISIS WEBSITE QUALITY, TRUST DAN LOYALTY PELANGGAN ONLINE SHOP. Jurnal Manajemen Pemasaran. https://doi.org/10.9744/pemasaran.8.2.55 $-61$

\section{Sumber Lain}

www.APJII.com

www.Kompas.com

www.Marketing.com

www.CHIP.CO.ID

www.Seluler.id

www.bukalapak.com 